\title{
Proximal Input of Polynuclear Aromatic Hydrocarbons (PAHs) in Groundwater Sources of Okrika Mainland, Nigeria
}

\author{
C. G. Okoli, D. H. Ogbuagu", C. L. Gilbert, S. Madu, R. F. Njoku-Tony
}

Department of Environmental Technology, Federal University of Technology, Owerri, Nigeria. Email: henrydike2002@yahoo.com

Received April 14 ${ }^{\text {th }}, 2011$; revised May 26 ${ }^{\text {th }}, 2011$; accepted July $9^{\text {th }}, 2011$.

\begin{abstract}
The Port Harcourt Refinery Company situated at Okrika Mainland discharges its effluent into the Creeks surrounding this coastal land. The current study examined the presence of polynuclear aromatic hydrocarbons in groundwater sources of the coastal settlement. Ten replicate samples were collected from 10 boreholes in the settlement using sterilized amber glass bottles and fixed with concentrated $\mathrm{H}_{2} \mathrm{SO}_{4}$. They were later analyzed using Gas chromatography (GC). The Pearson product moment correlation coefficient $(r)$ was used to determine the interactions of the PAHs detected while the One-way ANOVA was used to determine spatial variance equality in means of the PAHs components at $P<$ 0.05 . Further structure detection was made with means plots, utilizing $\mathrm{pH}$ as a predictor variable. High concentrations of PAHs which exceeded the WHO maximum permissible limit for the PAHs in drinking water $(0.002 \mathrm{mg} / \mathrm{L})$ were recorded from the borehole samples. Acenaphthene had the highest concentration of $0.88317(0.202494 \pm 0.0652) \mathrm{mg} / \mathrm{L}$, while acenaphthylene had the least maximum concentration of $0.18837(0.04978 \pm 0.0123)$. However, naphthalene recorded concentrations of between 0.00058 and $0.52510(0.0874576 \pm 0.03472) \mathrm{mg} / \mathrm{L}$, fluorene 0.00018 and 0.20438 $(0.0527435 \pm 0.01564) \mathrm{mg} / \mathrm{L}$, phenanthrene 0.00041 and $0.26732(0.0603780 \pm 0.018634) \mathrm{mg} / \mathrm{L}$, and anthracene between 0.00029 and $0.25084(0.0692785 \pm 0.0176569) \mathrm{mg} / \mathrm{L}$. There was significant variance inequality in means of the PAHs measured across the sampling locations at $P<0.05\left[F_{(971.1318)}>F_{\text {crit(3.85563) }}\right]$. A further structure detection revealed that the inequalities were contributed by all the $P A H$ components, especially between $B H 3$ and $B H 1, B H 4$ and $B H 2$ and 5, as well as between $B H 6$ and $B H 10$. Very strong associations were observed between the PAH components at $P<0.01$. BH 8 recorded the highest contamination level of the various PAHs due basically to its proximity to the refinery's effluent discharge point (Ekerekana Creek) and channel. Hence the source of these pollutants could best be fingerprinted to the nearby Port Harcourt Refinery Company's effluent discharges. These PAHs are not only ingested by drinking contaminated waters, but are further consumed when this water is used to prepare foods. This creates a great cause for public health concerns especially as several PAHs are known carcinogens. It is therefore, recommended that technologically advanced techniques of water treatment be developed in order to take care of the presence of PAHs in drinking water sources of the coastal dwellers.
\end{abstract}

Keywords: Carcinogenic, Polynuclear Aromatic Hydrocarbons, Groundwater, Gas Chromatography, Okrikamainland

\section{Introduction}

Crude oil refining processes generates a lot of solid, liquid, and gaseous wastes into the environment. The liquid wastes, collectively called effluents are usually discharged into nearby water bodies by operators. One of the toxic components of crude oil are the polynuclear aromatic hydrocarbons (PAHs). According to ATSDR [1], PAHs are generally formed during the incomplete combustion of coal, oil, gas, wood, or other organic sub- stance such as tobacco and charbroiled meat, and have been reported to be the most abundant of the main hydrocarbons found in crude oil mixture [2,3]. They have also been identified in soils at uncontrolled disposal sites, including wood preservation, oil wastes, and coal gasification sites [4]. Marten and Frankenberger, Jr., [5] estimated that the half-life of PAHs can range from as short as 2 days (for naphthalene) to almost 400 days (for fluoranthene) in soils. Anthropogenic sources such as industrial production, transportation and waste incineration 
also generate significant amounts of PAHs [6].

They resist degradation and are able to be retained in sediments and could also accumulate in fatty tissues and thus pass up the food chain, eventually to man $[7,8]$.

Groundwater pollution from PAHs is possible and the use of this water for domestic purpose represents a risk to human health and safety [9]. It is a worldwide problem that often emanates due to the seepage of contaminants from waste disposal sites, oil spills, surface and underground storage tank leakages, agricultural activities, effluent discharges, etc. [10] Such contamination of groundwater resources potentially poses a substantial risk to local resources users and to the natural environment [11].

The main source of drinking water in Okrika Mainland, a coastal settlement, is groundwater, which is pumped from wells drilled into aquifers; some of which are shallow hand-dug wells while others are deep wells. In recent times, there have been public complaints of drinking odorous and crude oil-tainted waters, as well as observations of the formation of oil films on waters surfaces sourced from the community boreholes by inhabitants of the mainland. The porous soil and high water table in the settlement, together with the environmentally unfriendly method of discharge of oily effluents by the nearby refinery could thus provide a fingerprint to the contribution of the suspected contaminants to groundwater source. This contamination, unknown to the consumers may contain some concentrations of PAHs, some of which have been classified by the WHO and ATSDR as carcinogenic $[1,12]$. Consumption of these waters could therefore pose a health risk to members of the community.

Unfortunately, no research work has been carried out on the assessment of polynuclear aromatic hydrocarbons in ground water sources of this mainland, even as inhabitants continue to use them. It is therefore necessary to carry out an assessment of the presence of these toxic pollutants in groundwater sources of this area of the Niger Delta of Nigeria.

\section{Materials and Methods}

\subsection{Study Area}

Okrika, Rivers State falls within the Niger Delta area of Nigeria and is spatially located between latitude $04^{\circ}$ and $50^{\prime} \mathrm{N}$, and longitude $07^{\circ}$ and $10^{\prime} \mathrm{E}$ (Figures $\mathbf{1}$ and 2). About $95 \%$ of the total area is wetland; characterized by a network of meandering water channels, comprising mainly of creeks and small rivers which drain into short swift coastal rivers. The geology of Okrika is of the earlier deposits of the marine sediments of the Lower and Upper Cretaceous age, and it constitutes the economically important structure where petroleum was formed and preserved. The soil prevalent in the area could be classified as coarse, loamy, highly weathered, and moderately acidic with low soluble salt content. The pristine vegetation is characterized by thick mangrove forest of

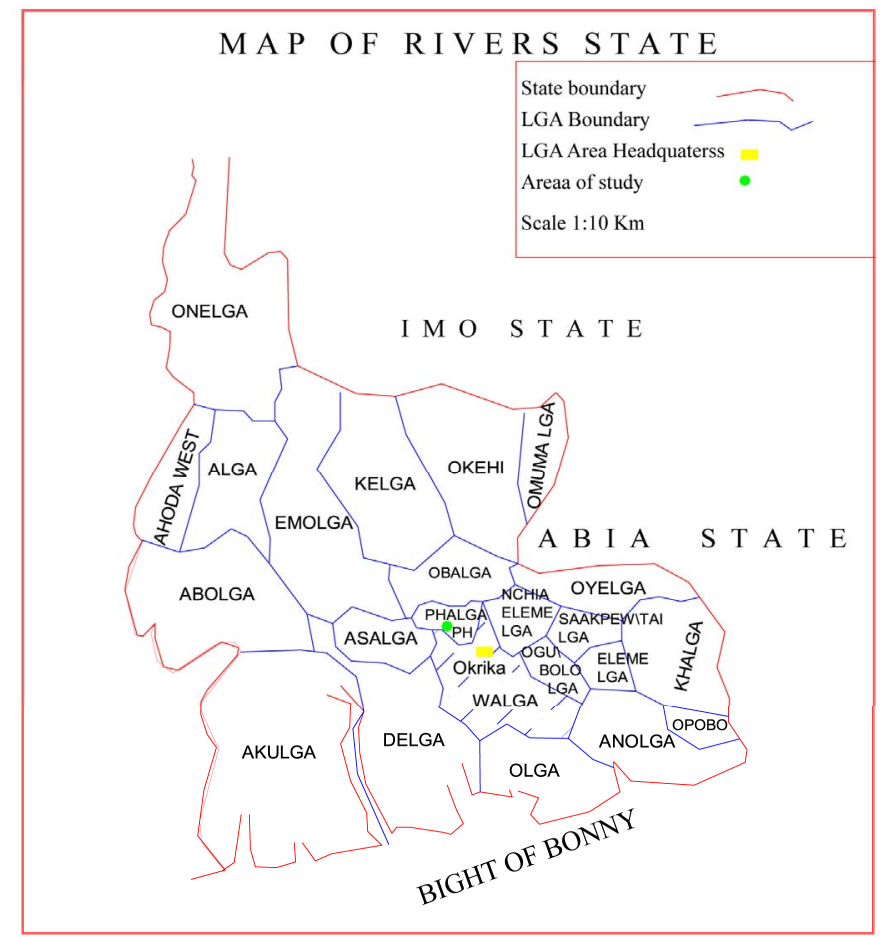

Figure 1. Map of Rivers State showing Okrika Local Government Area. 


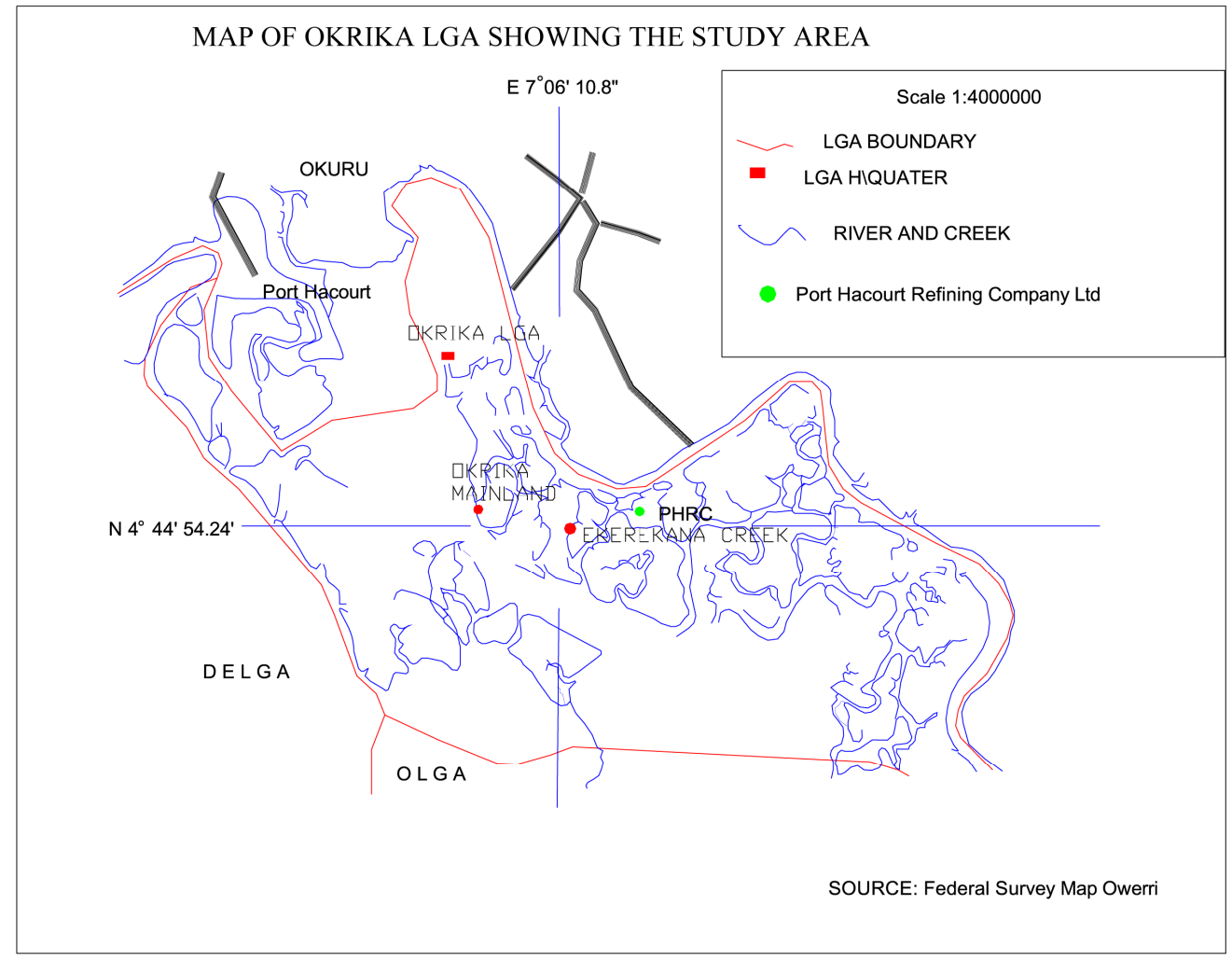

Figure 2. Map of Okrika LGA showing the study area.

the red variety type which attains heights up to $50 \mathrm{~m}$ and girth up to $27 \mathrm{~m}$, though urban and industrial developments have reduced them to secondary growth, and caused a drastic reduction in height and girth. The climate is tropical and characterized by frequent precipitation which reaches $300-450 \mathrm{~cm}$ annually; with a long wet season (March-September). Mean monthly temperature range between $24^{\circ} \mathrm{C}$ and $27^{\circ} \mathrm{C}$ and humidity is about $80 \%$ [13]. The major economic activity of the people is fishing.

\subsection{Field Sample Collection}

Two replicate water samples were collected from each of 10 boreholes, using 1 liter amber glass bottles fitted with a screw cap and lined with foil and labeled BH1, BH2, $\mathrm{BH} 3, \mathrm{BH} 4, \mathrm{BH} 5, \mathrm{BH} 6, \mathrm{BH} 7, \mathrm{BH} 8, \mathrm{BH}$, and $\mathrm{BH} 10$. Samples were transported to the laboratory as soon as possible in ice-packed cooler to maintain their integrity.

\subsection{Apparatus}

A gas chromatograph coupled with flame ionization detector (GC-FID model HP 5890); utilizing the column chromatograph for cleaning of sample extracts was utilized in the analysis of samples. Glasswares were all washed with detergents and hot water and subsequently rinsed with distilled water.

\subsection{Reagents}

All chemicals used are of analytical grade and of highest purity. Reagents used include N-hexane (solvent), silica gel (GC grade) as desiccant, conc. $\mathrm{H}_{2} \mathrm{SO}_{4}$ (for preservation of samples), and reagent water (prepared by passing tap water through a carbon filter bed containing about $0.5 \mathrm{~kg}$ activated carbon, using a water purification system). A PAH standard mixture containing 1000 ppm each of naphthalene, acenaphthylene, acenaphthene, fluorene, phenanthrene and anthracene was used.

\subsection{GC Parameters}

The GC parameters used include helium (carrier gas), air and hydrogen(fuel gases), nitrogen (back up gas), detector temperature of $35^{\circ} \mathrm{C}$, in-let temperature of $25^{\circ} \mathrm{C}$, initial and final temperatures for oven of $5^{\circ} \mathrm{C}$ and $300^{\circ} \mathrm{C}$, respectively, hydrogen, air, nitrogen, and helium flow rates of $30,300,30$, and $30 \mathrm{ml} /$ minute, respectively.

\subsection{Sample Extraction}

About $50 \mathrm{ml}$ of borehole water was measured into 1 liter separating funnel.1 drop of concentrated $\mathrm{H}_{2} \mathrm{SO}_{4}$ was added to the sample in the separating funnel to release the hydrocarbon components. $5 \mathrm{ml}$ of the solvent $(\mathrm{N}$ hexane) was added to the sample and samples vigorously 
shaken for 5 minutes and allowed to stand for another 20 minutes. Layers were formed that separated the extract (the top layer) from the lower layer (which was discarded) and the extract collected for GC analysis in a glass vial.

\subsection{Cleaning of Extract}

A column chromatography was set up using silica gel and a glass wool and extracts passed through the column to clean and remove biogenics.

\subsection{GC Analysis}

Cleaned extract was loaded using micro-GC syringe and the GC prompted to run for about 41 minutes. At the end, results containing the chromatograms were integrated and printed.

\section{Statistical Analysis}

The Pearson product moment correlation coefficient (r) was used to determine the interactions of the PAH components detected. Furthermore, the one-way ANOVA was used to determine spatial variance equality in means of $\mathrm{PAH}$ variables at $\mathrm{P}<0.05$, and subsequently structure detection made with means plots.

\section{Results}

\subsection{Variations in PAH Concentrations in Groundwater Sources}

Wide variations were observed in the concentrations of the component PAHs detected in the groundwater samples (Table 1). Naphthalene concentration ranged between 0.00058 and $0.52510(0.087458 \pm 0.0347) \mathrm{mg} / \mathrm{L}$, acenaphthylene ranged between 0.00041 and 0.18837 $(0.04978 \pm 0.0123) \mathrm{mg} / \mathrm{L}$, acenaphthene between 0.00053 and $0.88317(0.202494 \pm 0.0652) \mathrm{mg} / \mathrm{L}$, and fluorene between 0.00018 and $0.20438(0.052744 \pm 0.0156) \mathrm{mg} / \mathrm{L}$. However, phenanthrene and anthracene concentrations ranged from $0.00041-0.26732(0.060378 \pm 0.0186)$ and $0.00029-0.25084(0.069279 \pm 0.0177) \mathrm{mg} / \mathrm{L}$, respectively.

Table 1. Variations in PAHs concentration $(\mathrm{mg} / \mathrm{L})$ of groundwater samples in Okrika Mainland.

\begin{tabular}{ccccc}
\hline PAH & Minimum & Maximum & Mean & SE \\
\hline Naphthalene & 0.00058 & 0.52510 & 0.0874576 & 0.03471941 \\
Acenaphthylene & 0.00041 & 0.18837 & 0.0497795 & 0.01230182 \\
Acenaphthene & 0.00053 & 0.88317 & 0.2024935 & 0.06519860 \\
Fluorene & 0.00018 & 0.20438 & 0.0527435 & 0.01564219 \\
Phenanthrene & 0.00041 & 0.26732 & 0.0603780 & 0.01863347 \\
Anthracene & 0.00029 & 0.25084 & 0.0692785 & 0.01765686 \\
\hline
\end{tabular}

$\mathrm{SE}=$ standard error.

\subsection{Spatial Variations in PAHs}

All the PAH components (except anthracene) recorded highest concentrations in BH8. While acenaphthylene, acenaphthene, and anthracene recorded least concentrations of $0.00043,0.00056$, and $0.00029 \mathrm{mg} / \mathrm{L}$, respectively in $\mathrm{BH} 7$, fluorene and phenanthrene recorded least values of 0.00019 and $0.00041 \mathrm{mg} / \mathrm{L}$, respectively in $\mathrm{BH}$ 10 (Figures 3-5).

A test of variance equality using the analysis of variance (ANOVA) revealed high significant spatial inequality in means of the PAH concentrations across the borehole samples $\left[F_{(971.1318)}>F_{\text {crit(3.85563) }}\right]$ at $P<0.05$. A further structure detection utilizing $\mathrm{pH}$ as predictor in means plots revealed that the inequalities were contributed by all the PAH components measured. The highest inequalities were observed between $\mathrm{BH} 3$ and $\mathrm{BH} 1, \mathrm{BH} 4$

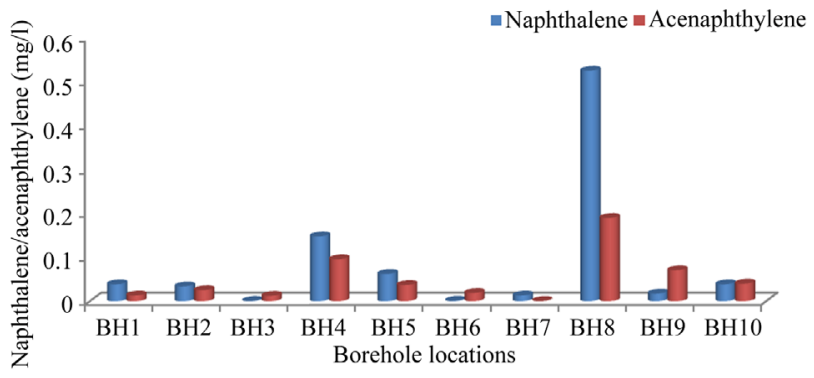

Figure 3. Spatial variation in naphthalene and acenaphthylene concentrations of groundwaters of Okrika Mainland.

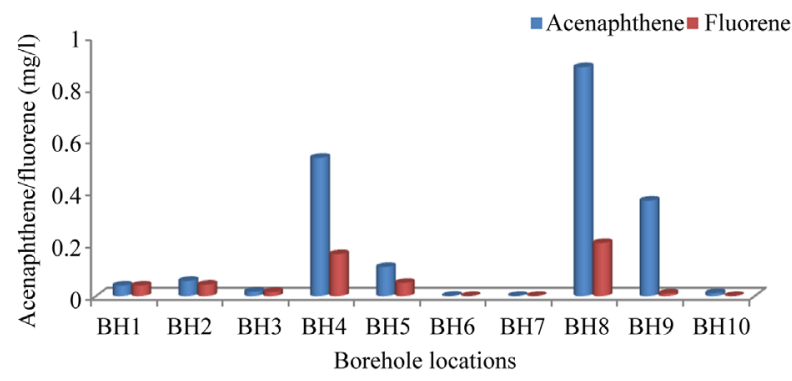

Figure 4. Spatial variation in acenaphthene and fluorene concentrations of groundwaters of Okrika Mainland.

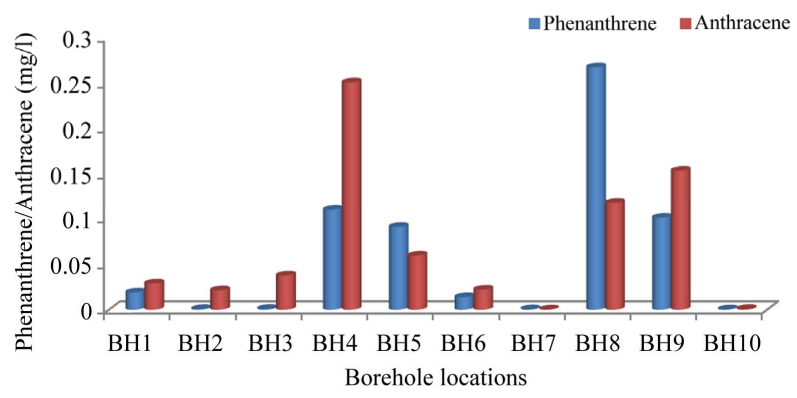

Figure 5. Spatial variation in phenanthrene and anthracene concentrations in groundwaters of Okrika Mainland. 
and $\mathrm{BH} 2 \& 5$ and between BH6 and BH10 (Figures 6-11), while the least inequality was observed between BH 5 and BH 6. However, no inequality was observed between $\mathrm{BH} 1$ and $\mathrm{BH} 4$.

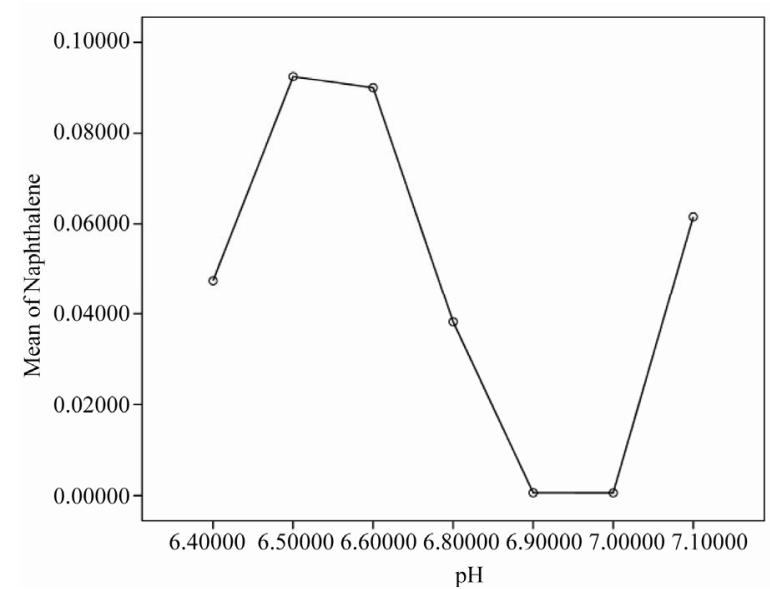

Figure 6. Structure detection in naphthalene concentrations using means plot.

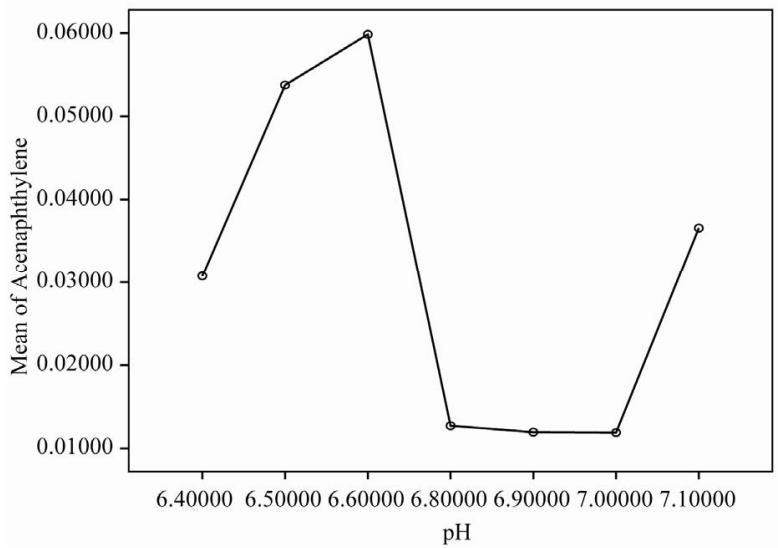

Figure 7. Structure detection in acenaphthylene concentrations using means plot.

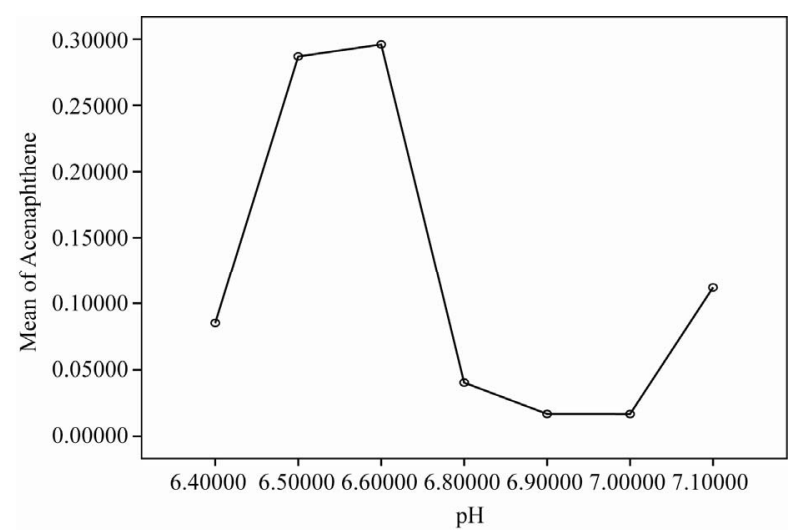

Figure 8. Structure detection in acenaphthene concentrations using means plot.

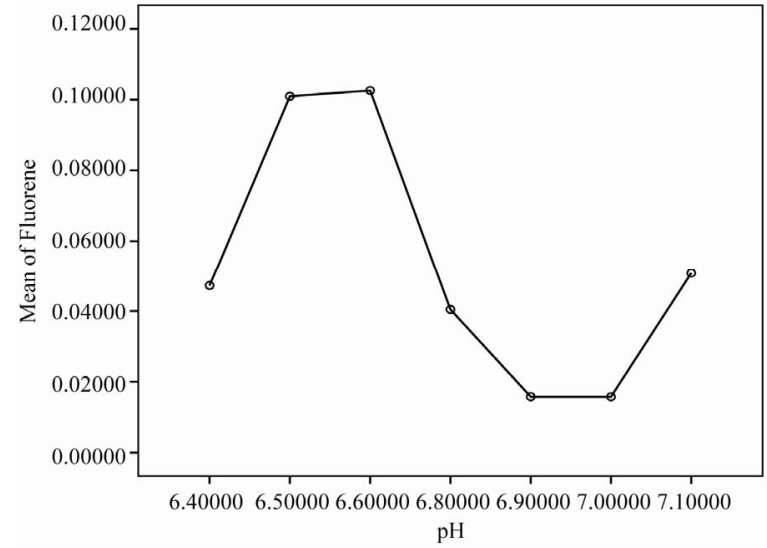

Figure 9. Structure detection in fluorene concentrations using means plot.

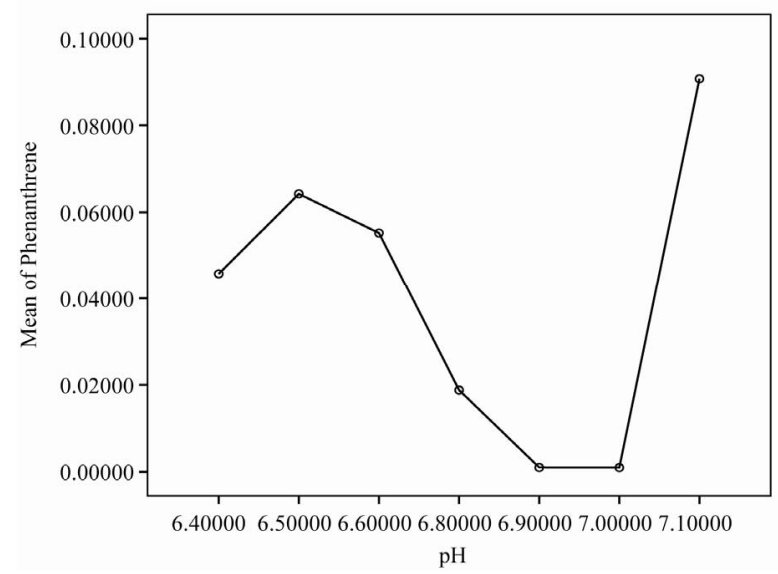

Figure 10. Structure detection in phenanthrene concentrations using means plot.

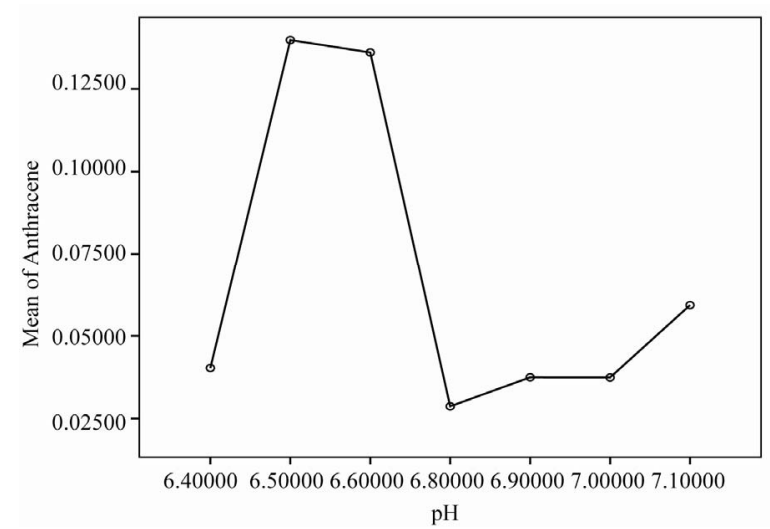

Figure 11. Structure detection in anthracene concentrations using means plot.

\subsection{Relationship between Polynuclear Aromatic Hydrocarbons}

Though $\mathrm{pH}$ had no significant influence on them, the 
PAHs showed very strong significant influences on one another. At $\mathrm{P}<0.01$, all the PAHs showed significant interactions with one another, except between naphthalene and anthracene (Table 2).

\section{Discussion}

The high concentrations of PAHs detected in the groundwater samples could readily be fingerprinted to petroleum contamination of the groundwater aquifers from the poorly treated refinery effluents in the neighbourhood. The refinery operators have continuously discharged oilcontaminated wastewaters into the surrounding Creeks bordering the small coastal settlement for some fourty five years now. The possibility of seepage and subsequent contamination of the groundwater aquifers by surface pollutants have been severally identified by other authors, $[14,15]$. [16] had also identified components of the PAHs in ground waters of some Niger Delta region of Nigeria; whereby he detected high concentrations of benzo(a)pyrene, especially in those sources from oil producing communities. The World Health Organization [17] has $0.002 \mathrm{mg} / \mathrm{L}$ as the maximum permissible limit for these PAHs in drinking water, besides that of benzo(a) pyrene $(0.0001 \mathrm{mg} / \mathrm{L})$, which corresponds to an excess life time cancer risk of $10^{-5}$. Values from this study far exceed this standard for PAHs. Undoubtedly, these results create a great cause for public health concerns, especially as PAHs have been confirmed to be carcinogenic [1], and are not only ingested by drinking contaminated waters alone, but also when the water is used to prepare foods, thereby increasing the risk of elevated concentrations in tissues of man and animals. Inevitably man suffers the greatest risk of bioaccumulation due to his position in the trophic chain; being a tertiary consumer in addition to his predisposition to other route of entry into his body. Worse still, carcinogenicity is transgenic, as oncogenes (cancer prone genes) could be inherited by filial generations $[18,19]$.

The significantly uncorrelated relationship between $\mathrm{pH}$ and $\mathrm{PAH}$ components imply that hydrogen ion concentration does not play any role in the biogeochemical availability of PAHs, rather their concentrations are anthropogenic in nature [1]. Moreover no research has shown any correlation between $\mathrm{pH}$ and PAHs. However the very strong significant associations observed between most of the polynuclear aromatic hydrocarbons agrees with the work of El-Deeb and Emara [20]. The source of PAHs in this study is therefore generally believed to be of petrogenic origin and components are closely related due to their molecular weights [21].

The observed spatial variations in PAH concentrations indicates differential levels as well as proximal inputs of contaminations in the boreholes. BH8, which had the highest concentrations of almost all the PAHs measured is located very close to the refinery's effluent discharge point (Ekerekana Creek). Similarly, BH 4, which is situated few meters from the Ogan waterside; a highly contaminated slow flowing Creek, also had very high concentrations of anthracene. In contrast, $\mathrm{BH} 10$ and $\mathrm{BH} 7$ which had the lowest level of contamination from most of the PAHs measured are located relatively far from the effluent discharge point and route. The source of their contamination could be relatively prolonged seepages from the surrounding Creeks.

\section{Summary, Conclusions and Recommendation}

Data obtained from this work revealed that the activities of a refinery can cause a serious contamination of groundwater supply of its host community, resulting in potential, chronic detrimental health effects. The observed spatial variation in concentrations indicates proximal inputs, even as the PAH components exhibited very high relatedness. The presence of these polynuclear aromatic hydrocarbons in alarming concentrations, higher than the stipulated maximum contamination level (MCL) of regulatory agency [17] calls for intervention to save the ignorant coastal dwellers from impending debilitating health problems.

The refinery's effluents should be properly treated and disposed of using environmentally friendly practices that are in line with regulatory standards and guidelines. Fur-

Table 2. Correlation matrix of the РАH components.

\begin{tabular}{|c|c|c|c|c|c|c|}
\hline & $\mathrm{pH}$ & Naphthalene & Acenaphthylene & Acenaphthene & Fluorene & Phenanthrene \\
\hline Naphthalene & -0.368 & & & & & \\
\hline Acenaphthylene & -0.310 & $0.932 * *$ & & & & \\
\hline Acenaphthene & -0.296 & $0.888^{* *}$ & $0.975^{* *}$ & & & \\
\hline Fluorene & -0.365 & $0.884 * *$ & $0.873 * *$ & $0.896^{* *}$ & & \\
\hline Phenanthrene & -0.150 & $0.909 * *$ & $0.955^{* *}$ & $0.955^{* *}$ & $0.847 * *$ & \\
\hline Anthracene & -0.222 & 0.399 & $0.637 * *$ & $0.751 * *$ & $0.674 * *$ & $0.625 * *$ \\
\hline
\end{tabular}

$* *=$ significant at $\mathrm{P}<0.01$. 
thermore, strategies should be put in place by the company to contain the expanding groundwater plume. There is however the need for further research into the presence of PAHs in soils impacted by oil activities, the lives of aquatic organisms, macrobenthal organisms, plankton assemblages, microbial communities, and air in the industrial mainland.

\section{REFERENCES}

[1] Agency for Toxic Substances and Disease Registry (ATSDR), "Public Health Statement for Polycyclic Aromatic Hydrocarbons (PAHs)," Agency for Toxic Substances and Diseases Registry (ATSDR), US Department of Health and Human Services, Public Health Services, Atlanta, 1995.

[2] A. Masih, R. Saini and A. Taneja, "Contamination and Exposure Profiles of Priority Polycyclic Aromatic Hydrocarbons (Pahs) in Groundwater in a Semi-Arid Region in India," International Journal of Water, Vol. 4, No. 1-2, 2008, pp. 136-147. doi:10.1504/IJW.2008.018152

[3] O. Duke, "Source Determination of Polynuclear Aromatic Hydrocarbons in Water and Sediment of a Creek in the Niger Delta Region," African Journal of Biotechnology, Vol. 7, No. 3, 2008, pp. 282-285.

[4] R. J. Mahmood, "Enhanced Mobility of Polynuclear Aromatic Hydrocarbons in Unsaturated Soil," Ph.D. Thesis, Department of Civil Environmental Engineering, Utah State University, Logan, 1989.

[5] D. A. Martens and T. Frankenberger Jr., "Enhanced Degradation of Polycyclic Aromatic Hydrocarbons in Soil Treated with an Advanced Oxidative Process-Fenton's Reagent," Journal of Soil Contamination, Vol. 4, No. 2, 1995, pp. 175-190.

[6] H. H. Yang, W. J. Lee, S. J. Cheng and S. O. Lai, "PAH Emission from Various Industrial Stacks," Journal of Hazardous Materials, Vol. 60, No. 2, 1998, pp. 159-174. doi:10.1016/S0304-3894(98)00089-2

[7] J. C. Decker, "Potential Health Hazards of Toxic Residues in Sludge. In Sludge-Health Risk of Land Application," Ann Arbor Science Publishers Inc., Ann Arbor, 1981, pp. 85-102.

[8] P. D. Boehm, D. L. Fiest and A. Elskus, "Comparative Weathering Patterns of Hydrocarbons from Amoco Cadiz Oil Spill Observed at a Variety of Coastal Environment," International Symposium on the Fate and Effects of Oil Spill, Brest, 7 October 1981, pp. 159-173.

[9] U. Forstner and G. T. W. Wittmann, "Metal Pollution in the Aquatic Environment," Spring-Verlag, New York, 1993.

[10] R. S. Sharma and T. S. Al-Busaidi, "Groundwater Pollution Due to a Tailings Dam," Engineering Geology, Vol. 60, No. 1-4, 2001, pp. 235- 244. doi:10.1016/S0013-7952(00)00104-6

[11] M. Abolfazi and A. P. Elahe, "Groundwater Quality and the Sources of Pollution in Baghan Watershed, Iran," Journal of World Academy of Science, Vol. 43, 2008, pp. 28.

[12] World Health Organizations (WHO), "Non-heterocyclic Polycyclic Aromatic Hydrocarbons," Environmental Health Criteria, International Programme on Chemical Safety, World Health Organization, Geneva, Vol. 202, 1997.

[13] Shell Petroleum Development Company of Nigeria Limited (SPDC), "Environmental Impact Assessment of Obigbo Node Associated Gas Gathering Project," Final Report, Tial Trade Limited, 1998.

[14] P. Narayanan, "Environmental Pollution: Principles, Analysis and Control," CBS Publishers \& Distributors, New Delhi, 2007, p. 659.

[15] R. Kaufmann and C. Claveland, "Environmental Science," McGraw-Hill International, New York, 2008.

[16] C. Anyakora, A. Ogbeche, H. Coker, G. Ukpo and C. Ogoh, "A Screen for Benzo(a)pyrene, a Carcinogen in the Water Samples from the Niger Delta Using GC-MS," Nigerian Quarterly Journal of Hospital and Medicine, Vol. 14, No. 3-4, 2004, pp. 288-293.

[17] World Health Organization (WHO), "Guidelines for Drining Water Quality," Geneva, 1984.

[18] H. J. Evans, "Molecular Mechanisms in the Induction of Chromosome Aberration," In: D. Scott, B. A. Bridges and F. H. Sobels, Eds., Progress in Genetic Toxicology, 1977, pp. 57-74.

[19] M. Cerna, "Mutagenicity Testing of Environmental Complex Mixtures (Air, Drinking Water, Industrial Effluents, Soil, etc.)," In: Abstract Book, INREG, Rockilde University, Rockilde, 1996, p. 4.

[20] M. K. Z. El-Deeb and H. I. Emara, "Polycyclic Aromatic Hydrocarbons and Aromatic Plasticizer Materials in the Seawater of Alexandria Coastal Area," Egyptian Journal of Aquatic Research, Vol. 31, 2005, pp. 15-24.

[21] D. Okoro, "Source Determination of Polynuclear Aromatic Hydrocarbons in Water and Sediments of a Creek in the Niger Delta Region," African Journal of Biotechnology, Vol.7, No. 3, 2007, pp. 282-285. 